\title{
"It's not 30 pesos. It's 500 years": monuments, memory and activism in the Wallmapu during the estallido social in Chile $^{*}$
}

\author{
"No son 30 pesos. Son 500 años.": Monumentos, memoria y \\ activismo en el Wallmapu durante el estallido social en Chile"
}

Alexander Ulrich Thygesen ${ }^{* *}$

\begin{abstract}
This article studies to what extent the interaction between activists and historical monuments during the 2019 Chilean protests created a shift in the interpretation of the country's past, thus facilitating the emergence of alternative and more inclusive narratives able to challenge hegemonic power structures. The article embarks on this endeavour through an analysis of three cases of demonumentalisation that occurred in the Chilean city of Temuco on the 29th of October 2019. Methodologically, the article engages with a combination of theories regarding the coloniality of power, the politics of aesthetics, and cultural memory. Finally, the paper concludes by arguing that Chilean activists' engagement in the practice of demonumentalisation exposed alternative narratives concerning the historical conflict between the Chilean state and the Mapuche community. Making visible the perpetuation of unjust social structures in Chilean society and creating bonds of solidarity between the Chilean mass movement and the Mapuche movement.
\end{abstract}

Keywords: Demonumentalisation, Chilean social outbreak, the distribution of the sensible, Implicated subject, the coloniality of power.

\footnotetext{
* The article is a modified version of a conference paper that I presented at the Mnemonics Summer School 2021 on the 18th of August. The event was held at Sandbjerg Manor, Denmark. The paper was part of the panel "Public Space and Memory Practices" that was chaired by Prof. Jessica Ortner, from the University of Copenhagen. Prof. Michael Rothberg from the University of California, Los Angeles, was the discussant. The theoretical framework has been slightly modified for the published version, along with other minor changes in the text.
}

** Dane. PhD student. Aarhus University. Aarhus, Dinamarca. aut@cc.au.dk 


\section{RESUMEN}

El presente artículo estudia la interacción entre activistas y mo-

Palabras clave: numentos históricos durante las protestas chilenas de 2019. Lo hace para investigar en qué medida la practica de desmonumentalización generó un cambio en la interpretación del pasado del país, facilitando de esta manera el surgimiento de narrativas alternativas y más incluyentes que desafiaron las estructuras de poder hegemónico. El artículo emprende esta tarea a través de desmonumentalización, estallido social, reparto de lo sensible, sujeto implicado, colonialidad de poder. un análisis de tres casos de desmonumentalización que ocurrieron en la ciudad chilena de Temuco el 29 de octubre de 2019. Metodológicamente el análisis combina enfoques teoréticos como la colonialidad de poder, la política de la estética y la memoria cultural. Por último, el artículo concluye que la participación de activistas chilenas en las prácticas de desmonumentalización fomentó narrativas alternativas sobre el conflicto histórico entre el estado chileno y la comunidad Mapuche, haciendo visible la perpetuación de estructuras sociales injustas en la sociedad y construyendo lazos de solidaridad entre el movimiento masivo y el movimiento mapuche. 


\section{Introduction}

Chilean actress Susana Hidalgo took a famous series of photos (w/p) during the first week of the largest social mobilisation in Chile's history, which began in October 2019 and became known as the Estallido Social (ES), or the "Social Outbreak." Student-led protests against an increase of 30 pesos in metro fares in the Chilean capital, Santiago, ignited the ES. The protests rapidly evolved into a mass movement whose primary opponent became the neoliberal socio-economic model that the country inherited from the military junta led by General Augusto Pinochet (1973-1990) (Arias-Loyola 3-4). Hidalgo took the photos in the centre of Santiago, more specifically on the former Plaza Baquedano. This public space was symbolically renamed Plaza de la Dignidad (Dignity Square) by activists and served as the focal point of the ES (Quezada Vásquez and Alvarado Lincopi, "Repertorios anticoloniales..." 6). In one of the photos by Hidalgo, a blue, green, and red flag appears in the hand of an activist on top of the equestrian monument of General Baquedano, a $19^{\text {th }}$-century military man and politician. The banner is the Wenufoye, the flag of the Mapuche indigenous community in Chile. It raises the question: What was the flag doing up on that statue during the ES?

In this article, I will explore the entanglements between the Mapuche community and the Chilean mass movement to provide a preliminary answer to how a conflict concerning 30 pesos developed into a conflict concerning 500 years of colonialism. To do this, it is necessary to study what Ann Rigney has called the memory-activism nexus (Rigney, "Remembering Hope..." 372). This will be done through an analysis of an emblematic case of the interaction between activists and monuments. During the mobilisation, a vast number of monuments and statues were dismantled, remodelled, or replaced by protestors (Alvarado Lincopi and Quezada Vásquez, "Derribar..." 1). These popular practices were in many ways connected with narratives of colonisation and the polemical relationship between the Chilean state and the Mapuche community (Martínez 31-32). The case in question revolves around the events that unfolded in the southern city of Temuco on the 29th of October 2019. Here activists tore down three different statues and rearranged them in the public space. The analysis will attempt to answer the following research question: To what extent did the interac- 
tion between Chilean activists and historical monuments create a shift in the interpretation of the country's past, thus facilitating the emergence of alternative and more inclusive narratives that challenged existing power structures? To do so, I will engage with theories regarding the coloniality of power, the politics of aesthetics and cultural memory, which will be presented briefly in a later section.

\section{The Mapuche Movement in the Estallido Social}

The Mapuche community has been an internal "other" within Chilean society since the colonial period (Huinca-Piutrin, "El derribo..." w/p). The community has historically been subjected to violent Chilean colonial expansion, especially during the "Pacification of the Araucanía" campaign (1861-1883), where large parts of the Mapuche homeland in the south, the Wallmapu, was usurped by the Chilean state (Richards 39). Later, the indigenous community's support for the Unidad Popular government (1970-1973), led by President Salvador Allende, turned the Mapuche into targets of political repression after the Allende government was toppled by the military junta led by General Pinochet in 1973 (60-61). The neoliberal reforms that the Pinochet regime put into place in the following two decades disadvantaged the Mapuche and paved the way for an increase in the exploitation of natural resources in the Wallmapu by large corporations (60-61).

Consequently, a Mapuche movement has for decades been fighting for indigenous rights and self-determination (Tricot 127). Tito Tricot has argued that this established Mapuche movement and the mass movement that emerged during the ES were united by their experiences of state violence (124). The majority of Chilean society became acquainted with state violence during the violent years of the dictatorship and the first democratic governments' crackdowns on social mobilisation, while the Mapuche community had experienced it for centuries (124). This provides an explanation for the Mapuche movement's rewriting of the mass movement's slogan "It's not 30 pesos. It's 30 years" to "It's not 30 pesos. It's 500 years" (Huinca-Piutrin, "No son 30 pesos..." w/p). The rewriting of the slogan seemed to serve as a reminder for the Chilean protesters that the Mapuche were not just fighting against the legacy of the dictatorship, but also the legacy of colonialism. 
As a direct consequence of the mobilisation in 2019, a constitutional process was approved through a plebiscite in October 2020. 78 percent of voters favoured the drafting of a new constitution that would replace Pinochet's Magna Carta from 1980 (Bonnefoy w/p). Subsequently, the political elite in Chile suffered a severe defeat in the elections for the Constitutional Convention, the constituent body that will be in charge of drafting the new constitution (Sherwood et al. w/p). This cleared the way for the election of the Mapuche academic, Elisa Loncón, as President of the Constitutional Convention in July 2021 (Ontiveros w/p). Loncón emphasised this historic moment in her inauguration speech: "I'm grateful for the support of the different coalitions that placed their trust and their dreams in the hands of the Mapuche nation, who voted for a Mapuche person, a woman, to change the history of this country" (qtd. in Ontiveros w/p).

\section{Theoretical framework}

The interaction between activists and monuments during the ES was dominated by the practice of demonumentalisation (Alvarado Lincopi and Quezada Vásquez, "Derribar..." 1). In its most literal sense, the concept signifies the act of tearing down statues and monuments but has also recently been expanded to encompass the substitution and saturation of monuments by activists (3-7). In this study, I argue that the concept of demonumentalisation can be viewed as a type of performance. Here I follow the work of Diana Taylor, who defines performance as an act that "makes visible other cultural trajectories and permits us to resist the dominant construction of artistic and intellectual power" (Taylor 19).

To provide an approximate answer to how the selected case of demonumentalisation affected the memory discourse in Chile, I have chosen a threefold theoretical approach that combines the work of decolonial thinker Aníbal Quijano, the philosopher Jacques Rancière and finally the memory studies scholar Michael Rothberg. The three theoretical arenas that I combine in this paper would all be able to shed light on the practice of demonumentalisation independently, but I argue that the combination of the three theories and their associated concepts provides a more exhaustive illumination of the plethora of different complex processes that the practice of demonumentalisation encompasses. 
I make use of Quijano's concept of the coloniality of power to understand what type of unequal power structures that originates from the historical conflict between the Mapuche community and the Chilean colonial state and modern republic that was briefly described in the section above. According to Quijano, the coloniality of power is to be understood as the "racial" social classification of the world population that became the cornerstone of the Eurocentric capitalist colonial/modern world power (Quijano, "Coloniality and..." 171; Quijano, "Coloniality of power..." 533; Quijano, "Colonialidad del poder..." 342). The coloniality of power originates from the colonial structure of power imposed on the native population of the Americas by European colonisers starting from the 15th century, that has since outlived the political order of colonialism ("Coloniality and" 168-69). The racial hierarchy that was introduced in the colonies divided the population into dominating and superior Europeans and dominated and inferior non-Europeans ("Colonialidad del poder..." 374). Quijano states that colonial repression "fell, above all, over the modes of knowing, of producing knowledge, of producing perspectives, images and system of images, symbols, modes of signification, over the resources, patterns and instruments of formalized and objectivised expression, intellectual or visual" ("Coloniality and..." 169). This was followed by the imposition of the dominating group's own patterns of expression, and of their beliefs and images that restricted the cultural production of the dominated and proved to be an efficient means of social and cultural control ("Coloniality and..." 169). This coloniality of power thus facilitated the concentration of both cultural and material power in the hands of a small European minority in the colonies, whose descendants are still the principal beneficiaries of the continuation of this distribution of power ("Coloniality and..." 168).

To investigate how the performative practice of demonumentalisation exposed the perpetuation of the coloniality of power in Chilean society, I turn to the work of Rancière. More specifically, I argue that the practice of demonumentalisation induced a reconfiguration of the distribution of the sensible. Rancière (2013) defines the distribution of the sensible as "the system of self-evident facts of sense perception that simultaneously discloses the existence of something in common and the delimitations that define the respective parts and 
positions within it" (7). The distribution of the sensible thus describes the divide between the visible and the invisible in the intersection of aesthetics and politics. This condition can be observed in the practice of monumentalisation in Chile and the narratives of the past that are inherently fused with it. Here, the statues and monuments in the public space portray a glorified narrative of the past that favours the political elite and simultaneously neglects narratives concerning population groups that have traditionally been excluded from the centre of power in Chile, like the Mapuche (Quezada Vásquez and Alvarado Lincopi, "Repertorios anticoloniales..." 2-3; Alvarado Lincopi and Quezada Vásquez, "Derribar..." 2-3; Huinca-Piutrin, "El derribo..." w/p). Therefore, when Chilean activists engage in the practice of demonumentalisation, they impact the distribution of the sensible and impose a reconfiguration of the divide between the visible and the invisible regarding the dominant narrative of Chilean history. As Enzo Traverso has stated: “tearing down statues doesn't erase history, it makes us see it more clearly" (w/p).

Finally, to further enhance my argument I make use of the figure of the implicated subject and the coherent notion of implication, as recently conceptualised by Rothberg in his book The implicated subject: Beyond victims and perpetrators (2019). I do this to illuminate what type of narratives of the past emerged in the wake of the reconfiguration of the sensible embedded in the exposure of the coloniality of power. According to Rothberg, implicated subjects "occupy positions aligned with power and privilege without being themselves direct agents of harm; they contribute to, inhabit, inherit, or benefit from regimes of domination but do not originate or control such regimes" (1). They thus escape the traditional victim/perpetrator binary that has dominated the field of cultural memory studies during the last decades (Rigney 369; Rothberg 57). Approaching regimes of domination, like the colonial repression of the Mapuche in Chile, through the lens of implication, offers a way of addressing the "gain" from which implicated subjects profit via their direct or indirect connections to histories of perpetration (Rothberg 83). Implication does not equal complicity, as Rothberg stresses: "We are implicated in the past, ... but we cannot be complicit in crimes that took place before our birth" (14). 


\section{Temuco, $29^{\text {th }}$ of October 2019}

On the $29^{\text {th }}$ of October 2019, the Mapuche movement organized a protest march as a part of the mass mobilisation during the ES. The march took place in the city of Temuco, the regional capital of the Araucanía. During this march the statues of Pedro de Valdivia (1497-1553), Diego Portales (1793-1837) and Dagoberto Godoy (1893-1960) were torn down by activists (Watson w/p). These monuments were all part of what Mapuche historian Herson Huinca-Piutrin has called "the monumentalisation of a colonial historical memory in Chile" ("El derribo..." $\mathrm{w} / \mathrm{p}$ ). He is here referring to the large number of monuments depicting conquistadores, white statesmen, and military men in the urban centres of Chile ("El derribo..." w/p). The three demolished statues in Temuco can be divided into similar categories. Pedro de Valdivia was the 16th-century Spanish conquistador of Chile, and the founder of the Chilean colonial state, who died in the initial colonial war against the Mapuche ("Pedro de Valdivia..." w/p). Diego Portales was a $19^{\text {th }}$ century aristocratic statesman who is known as the architect of the Chilean authoritarian republic ("Diego Portales..." w/p). More so, he was the man behind the "Portalian Order," a political ideology of order and obedience from civil society in the face of state authority ("Diego Portales..." w/p). Finally, Dagoberto Godoy was a Chilean military pilot who played an important role in the initial steps towards the creation of a Chilean air force in the first part of the 20th century ("Los inicios..." $\mathrm{w} / \mathrm{p}$ ). The activists in Temuco targeted monuments depicting historic personalities that are connected directly or indirectly with the conflict between the Chilean state and the Mapuche community that span five centuries. Furthermore, the statues represent a narrative of Chilean national history that has favoured the country's dominating white elite and overshadowed the history of a major part of Chilean society, including the history of the indigenous communities (Huinca-Piutrin, “El derribo..." w/p). As Claudio Alvarado Lincopi and Ivette Quezada Vásquez have argued, the acts of demonumentalisation during the ES provided a way to secularise the saints of Chilean national history, whose statues have projected a glorified, white and homogenous interpretation of the past that tried to erase all traces of "the Indian," "the black" or "the mestizo" in the collective identity of the Chilean people (“Derribar..." 2-3). 
After being removed from their pedestals, the statues of Portales and Godoy were towed around Temuco by activists, a scene that can be observed in a video on Youtube by David Cárcamo (1:17-1:21). The two statues were at some point during the march towed to the statue of the Mapuche war leader Caupolicán (n.d.-1558), located in the centre of Temuco. The statue of Portales was placed at the feet of the monument to Caupolicán with the head facing towards the ground (Cárcamo 0:40$0: 46)$. The decapitated head from the statue of Godoy was later hanged in the hands of the Caupolicán statue that was simultaneously outfitted with a Wenufoye, as can also be observed in the video by Carcamo (1:33-1:45). This type of symbolic offering to monuments depicting historic indigenous leaders also occurred in Concepción, where the city's statue of Pedro de Valdivia was impaled and placed at the feet of a statue dedicated to the Mapuche war leader Lautaro (1534-1557) (Martínez 32).

The acts of demonumentalisation in Temuco and the subsequent remodelling of the Caupolicán monument all carry deep symbolic connotations in relation to Chilean national history. This is especially visible in how the head of the statue depicting Godoy, who represented the Chilean armed forces, is intentionally placed by activists in the hands of an icon of Mapuche resistance against colonial oppression. The action evokes the memory of the Chilean armed forces' role in countless acts of aggression against the Mapuche community (Richards 33-69; Huinca-Piutrin, "El derribo..." w/p) and provides a counter-narrative in which the vanquished historic Mapuche leader emerges victorious. I, therefore, agree with Nicolás Rojas Pedemonte and Diego Gálvez when they argue that the practice of demonumentalisation is not "mere acts of vandalism or destruction, but self-affirming initiatives that canalise transformative energy, reinforce identities and communicate the need to revert the still existing colonial order" (47).

I argue that it is relevant to interpret the transformative energy of the act of demonumentalisation in the context of the distribution of the sensible (Rancière 7). The energy embedded in the performative practice of demonumentalisation is exposed through the tearing down of the statues of a conquistador, an authoritarian 19th century politician, and a member of the Chilean armed forces. Here the demolition of the three statues and the later remodelling of the Caupolicán monu- 
ment in Temuco demonstrated a reconfiguration of the sensible that challenged the dominant interpretation of the past, formerly materialised in the demolished historical monuments. The activists acted as a demos, in a Rancièrian sense, where " . . those who have no business speaking, speak, and those who have no business taking part, take part" (Guénoun et al. 19). The demonumentalisation of a historical colonial memory in Chile (Huinca-Piutrin, "El derribo..." w/p) and the coherent reconfiguration of the sensible thus allowed for the emergence of new narratives of the past.

Moreover, I argue that it is beneficial to study this shift in the narratives of the past through the notion of implication, as conceptualized by Rothberg (1-2). The practice of demonumentalisation exposed the implication of Modern-day Chileans in the history concerning the centuries-old conflict between the Chilean state and the Mapuche community, a condition that was formerly disguised by the preceding distribution of the sensible that determined the divide between the visible and invisible in society. Pedemonte and Gálvez mention that the act of demonumentalisation communicates the need to revert the still existing colonial order (47). This resonates with Rothberg's statement that the responsibility of implicated subjects might be "to stop perpetuating and instead undo the deeds of their ancestors, but the need for such an undoing - decolonization, considered broadly — implies neither that the implicated subjects are guilty of the original crimes, nor, inversely, that their acts of decolonization could ever exonerate the perpetrators who committed the original deed" (142). Modern-day Chileans are thus not guilty of the extensive history of repression of the Mapuche community by the Chilean colonial state and the modern republic. Although, the revealing of their implication in these histories of perpetration may expose a need to confront and dismantled unequal power structures and their inherent racism that originates from the past. It is in this context that Quijano's concept of the coloniality of power provides a way to understand the type of unequal power structure that exists in the wake of colonialism.

The monumentalisation of a colonial historical memory in Chile (Huinca-Piutrin, "El derribo..." w/p) explicitly demonstrates the perdurance of the repression of the dominated group's patterns of expression and the subsequent imposition of the dominating group's 
own beliefs and images, as described by Quijano ("Coloniality and..." 169). Hence, the acts of demonumentalisation in Temuco and the counter-narrative present in the remodelling of the Caupolicán monument challenge this coloniality of power embedded in the dominant narrative of Chilean history and materialised through the act of monumentalisation. This is done by offering alternative interpretations of the past that reflect the notion of implication. Rothberg states that: "A clear understanding of one's own implication in multileveled conditions of violence and injustice is not a sufficient condition for social change, but it may be a necessary step for the creation of alliances among differently situated subjects" (33). Therefore, the mere fact that the practice of demonumentalisation reveals implication does not guarantee the dismantlement of the coloniality of power, but it may be an effective point of departure in the quest for decolonisation. However, the disclosure of implication in histories of perpetration may facilitate the emergence of solidarity across the divide between victims and beneficiaries (Rothberg 33). This is observable, I will argue, in the relationship between the Mapuche movement and the mass movement of the ES, as described by Tricot (129). This bond of solidarity between the two movements thus provides one explanation of the dismantlement, remodelling or replacement of a vast number of monuments by Chilean and Mapuche activists all over Chile during the historic uprising of 2019.

\section{Conclusions and broader perspectives}

Through the short analysis of the events in Temuco on the 29th of October 2019, it has been demonstrated that the activists' demonumentalisation of a colonial historical memory in Chile can be interpreted as a reconfiguration of the sensible, as understood by Rancière. This shift between the invisible and the visible in Chilean society facilitated the emergence of alternative narratives of the past. In this study, I have argued that Rothberg's theory concerning the implicated subject offers an effective theoretical lens through which these new narratives of the past can be analysed. Central to these narratives were the exposure of the notion of implication in Chilean society regarding the historical conflict between the Chilean state and the Mapuche community and the coherent perpetuation of the coloniality of power. Following Rothberg, I argued that the epiphany of implication embedded in the 
performative practice of demonumentalisation facilitated the creation of bonds of solidarity across the divide between victims and beneficiaries. These bonds were vital to the alliance between the Mapuche movement and the Chilean mass movement. Thus, we now see that the appearance of the Wenufoye on top of the Baquedano monument (Hidalgo $\mathrm{w} / \mathrm{p}$ ) bears testimony to the complexity of the entanglement between the Estallido Social and Chiles's polemical past. This entanglement encompasses a wide array of memories concerning not just the neoliberal dictatorship of Augusto Pinochet but also centuries of colonial repression of the Mapuche community and the unequal power structures that originate from the same.

On a final note, from the time of writing (September 2021), Chilean activists' extensive engagement in the practice of demonumentalisation during the ES can be seen as a clear precursor to the wave of iconoclastic activism that would hit the United States and then the rest of the world in the wake of the murder of George Floyd in May 2020. Even though the 2019 Chilean mass movement and the Black Lives Matter (BLM) movement inhabited different historical contexts and were triggered by two distinct events, they both strived for a more dignified future by challenging social structures that perpetuated injustice. As was the case with the Chilean mass movement, the BLM movement advocated for a more critical view on how histories of oppression are exhibited in public spaces in the shape of statues and monuments. This led to a multitude of cases of demonumentalisation where activists tore down or altered statues of colonisers, slave owners, explorers and other controversial historic figures all over the world, echoing the actions of Chilean activists months before.

\section{References}

Alvarado Lincopi, Claudio, and Ivette Quezada Vásquez. "Derribar, Sustituir y Saturar. Monumentos, Blanquitud y Descolonización". Corpus, vol. 11, no. 1. https://doi.org/10.4000/corpusarchivos.4560

Arias-Loyola, Martín. “Evade neoliberalism's Turnstiles! Lessons from the Chilean Estallido Social". Environment and Planning A: Economy and Space, vol. 53, no. 4, pp. 599-606. https://doi. org/10.1177/0308518X21997832 
Bonnefoy, Pascale. 'An end to the chapter of dictatorship': Chileans vote to draft a new constitution". The New York Times, 25 Oct. 2020, https://www.nytimes.com/2020/10/25/world/americas/chile-constitution-plebiscite.html

“Diego Portales Palazuelos (1793-1837)". Memoria Chilena, 2018, http://www.memoriachilena.gob.cl/602/w3-article-3358. html

Guénoun, Solange, et al. "Jacques Rancière: Literature, Politics, Aesthetics: Approaches to Democratic Disagreement". SubStance, vol. 29, no. 2, 2000, pp. 3-24, https://doi.org/10.2307/3685772

Huinca-Piutrin, Herson. "El derribo de estatuas en las plazas de Chile y Wallmapu. La des-monumentalización de los íconos de la memoria histórica colonial". Comunidad de Historia Mapuche, 15 Nov. 2019, https://www.comunidadhistoriamapuche.cl/el-derribo-de-estatuas-en-las-plazas-de-chiley-wallmapu-la-des-monumentalizacion-de-los-iconos-dela-memoria-historica-colonial/

“No son 30 pesos. Son 500 años": Los pueblos indígenas hacia la constitución de un Estado plurinacional"'. Mapuexpress, 1 Nov. 2019, https://www. mapuexpress.org/2019/11/01/\%E2\%80\%9Cno-son-30-pesos-son-500-anos\%E2\%80\%9D-los-pueblos-indigenas-hacia-la-constitucion-de-un-estado-plurinacional/

"Los inicios de la aviación militar chilena". Memoria Chilena, 2018, http://www.memoriachilena.gob.cl/602/w3-article-728. html

Martínez, José Luis. "Entre estatuas y memorias. Rompiendo una(s) historia(s) de lo nacional". Chile despertó: lecturas desde la historia del estallido social de octubre. Ed. Mauricio Folchi, Santiago, Universidad de Chile, 2019, pp. 28-43. Impreso.

Ontiveros, Eva. "Elisa Loncón: From poverty to $\mathrm{PhD}$ to writing Chile's constitution". BBC, 11 July 2021, https://www.bbc.com/ news/world-latin-america-57733539

Pedemonte, Nicolás Rojas and Diego Gálvez. "La protesta mapuche más allá (y más acá) del estallido social”. Anuario del Conflicto Social, no. 11, Jan. 2021. https://doi.org/10.1344/ ACS2020.11.4

“Pedro de Valdivia (ca. 1500-1553)". Memoria Chilena, 2018, http:// www.memoriachilena.gob.cl/602/w3-article-767.html 
Quezada Vásquez, Ivette and Claudio Alvarado Lincopi. "Repertorios anticoloniales en Plaza Dignidad: desmonumentalización y resignificación del espacio urbano en la revuelta. Santiago de Chile, 2019". Aletheia, vol. 10, no. 20, Oct. 2020, p. e049, https://doi.org/10.24215/18533701e049

Quijano, Aníbal. "Colonialidad del poder y clasificación social". Journal of World-Systems Research, vol. 11, no. 2, pp. 342-86.

"Coloniality and modernity/rationality". Cultural Studies, vol. 21, no. 2-3, pp. 168-78, https://doi. org/10.1080/09502380601164353

"Coloniality of power, eurocentrism, and Latin America". Nepantla: Views from South. Trad. Michael Ennis, vol. 1, no. 3, 2000, pp. 533-580.

Rancière, Jacques. The Politics of Aesthetics. Trad. Gabriel Rockhill. Bloomsbury Academic, 2013. Printed.

"Re-Evolución 25/10/2019". Instagram, uploaded by Susana Hidalgo, 25 Oct. 2019, https://www.instagram.com/p/B4EFvVzFcjv

Richards, Patricia. Race and the Chilean miracle: Neoliberalism, democracy, and indigenous rights. Pittsburgh, University of Pittsburgh Press, 2013. Printed.

Rigney, Ann. "Remembering hope: Transnational activism beyond the traumatic.' Memory Studies, vol. 11, no. 3, pp. 368-80, https:// doi.org/10.1177/1750698018771869

Rothberg, Michael. The implicated subject: Beyond victims and perpetrators. Stanford, Stanford University Press, 2019. Printed.

Sherwood, Dave, et al. "Chile's Govt in shock loss as voters pick independents to draft constitution". Reuters, 17 May 2021, https:// www.reuters.com/world/americas/chile-ruling-coalitionheading-disappointment-constitutional-delegates-vote-2021-05-17/

Taylor, Diana. "Introducción. Performance, teoría y práctica". Estudios Avanzados de Performance. Ed. Diana Taylor and Marcela Fuentes. México, D. F., Fondo de Cultura Económica, 2011, pp. 7-30. Impreso.

“Temuco 29 de Octubre". Youtube, uploaed by Daniel Cárcamo, 5 Dec. 2019, https://www.youtube.com/watch?v=nGQfwBzsDiU

Traverso, Enzo. “Tearing down statues doesn't erase history, it makes us see it more clearly". Jacobin, 24 June 2020, https://jacobinmag.com/2020/06/statues-removal-antiracism-columbus. 
Tricot, Tito. "El movimiento mapuche y la primavera chilena'. Anuario del Conflicto Social, no. 11, Jan. 2021, https://doi. org/10.1344/ACS2020.11.8

Watson, Johanna. "Temuco: más justicia, menos monumentos". $E l$ Desconcierto, 29 Nov. 2019, https://www.eldesconcierto.cl/ nacional/2019/11/29/temuco-mas-justicia-menos-monumentos.html 